\title{
Means and Mechanism of the Realization of Linguistic Subjectivity from the Perspective of Philosophical Cognition
}

\author{
BING ZHUAN PENG \\ School of Foreign Languages, Harbin University of Science and Technology, 52 Xuefu Road, Harbin, 150080, China \\ Email: pengbingzhuan@163.com
}

\begin{abstract}
This study discusses the linguistic subjectivity (LS) phenomenon from the perspective of philosophical cognition. The purpose of this study is to explore the human's cognitive styles and ways of existence in language and to deepen the understanding of communicative functions of language. An interactive geometric research framework of LS was constructed and the means and mechanism of its realization were explored at six levels: language system level, language use level, propositional meaning level, non-propositional meaning level, speaker's encoded meaning level and hearer's decoded meaning level. Also, three dimensions were covered: lexical dimension, syntactic dimension, and discourse dimension. Results show that humans' cognitive styles and ways of existence encoded in language can be more profoundly dug by exploring LS from the perspective of philosophical cognition. The study can provide a feasible analytical framework for systematically and comprehensively probing of LS phenomenon. Thus, the study facilitates a deeper understanding of LS and communicative functions of language. The study also thoroughly mines subjective factors behind the speaker's words, utterances or discourse, such as attitudes, emotions and feelings, which also belong to the cognition category, indicating the speaker's existence in language.
\end{abstract}

Keywords: linguistic subjectivity, philosophical cognition, means and mechanism of realization, cognitive styles, ways of existence

\section{INTRODUCTION}

Linguistic subjectivity (LS) is a cognitive and philosophical concept reflecting people's cognitive styles and serves as an existence way of people as meaning-expressing subjects in language. According to Peng, 'language is fundamentally inseparable from subjectivity... LS is the basic attribute of humans, and language cannot be known as language without it' (Peng 2019: 77). In the current study, LS is defined as the speaker's beliefs, opinions, feelings, attitudes, and emotions encoded in language.

In recent years, studies have extensively investigated LS (Nicholas 2015; Langacker 2019; Traugott 2019; Turner 2019; Vella, Gualeni 2019; Peng 2020). However, scholars explored such a concept mainly from the perspectives of semantics, cognitive linguistics, pragmatics, or philosophy and focused on its concrete means of realization. No systematic research 
framework has been formed. Therefore, constructing a reasonable and feasible geometric research framework from the perspective of philosophical cognition to explore means and mechanism of the realization of LS is significant. On the basis of the above discussion, an interactive geometric research framework of LS from the perspective of philosophical cognition was constructed to dig the means and mechanism of its realization systematically and comprehensively, aiming to explore the human's cognitive styles and ways of existence in language and the communicative functions of language.

\section{STATE OF THE ART}

Scholars conducted considerable work about LS, including its concept and the concrete means of its realization. According to Lyons, subjectivity refers to the phenomenon that 'the speaker, in making an utterance, simultaneously comments upon that utterance and expresses the speaker's attitude to what he is saying' (Lyons 1977: 739). However, he did not systematically expound on the specific means of the realization of LS. Petrovskaya and Haleem adopted a multilevel approach to explore how a socially responsible consumer behaviour (SRCB) is shaped by a combination of micro-level psychological drivers and specifics of the institutional context in which the behaviour is performed (Petrovskaya, Haleem 2020: 38), but the cognitive styles of the consumers received less attention. Mion and Adaui explored and described the multidimensional understanding of benefit and purpose of Italian benefit corporations, utilizing a qualitative and quantitative content analysis of 94 Italian benefit corporations' purpose declarations (Mion, Adaui 2020: 1). But the relations between people's behaviours and cognition were less mentioned. Paltrinieri studied the effects on neoliberal subjectivation, but only from the angle of duration (Paltrinieri 2017: 459).

How groups make moral decisions and how group preferences in moral decisions relate to overall group performance were explored (Curşeu et al. 2020: 820), but the role of individuals as the subjects in making moral decisions was not systematically mined. Gerner conveyed aspects of corporate sustainability across different socio-cultural contexts (Gerner 2019: 1). But the subjective factors and cognitive factors of the staff were less discussed. The subjectivity differences between chang chang (常常 in Chinese characters) and wang wang (往往 in Chinese characters), and their syntactic manifestations were investigated (Wang, Li 2019: 75). Yet, their study focused on the syntactic level of individual adverbs and thus lacked comprehensiveness. Consumers' opinions of benefits and attitudes which motivate companies to act in a socially responsible way were studied (Vuković et al. 2020: 528), but their study was confined to a questionnaire-based consumer research and lacked a theoretical framework.

Taking he qi (何其 in Chinese characters) and he deng (何等 in Chinese characters) as examples, Pan carried out a multidimensional study of their subjectivity (Pan 2018: 115), but he only focused on some adverbs. 'Reverse proportionality can arise from the underspecification of the measure function underlying the meanings of many and few' (Bale, Schwarz 2020: 673). However, little attention was paid to the role of humans in language. Moghaddam and Capone analysed Persian indirect reporting to determine the subjectivity and reflexivity in indirect reports (Moghaddam, Capone 2020: 14). Yet, social factors or the reporter's cognitive abilities were less considered. Almeida and Ulloa described the subjectification of the -ING construction from a conceptual approach (Almeida, Ulloa 2020: 443). They focused on functions of the - ING construction, but neglected the speaker's cognitive styles it manifests. Taking shui zhi dao (谁知道 in Chinese characters) as an example, Li and Luo discussed the speaker's cognitive position and subjectivity manifested by linguistic 
expressions (Li, Luo 2020: 44). Their study mainly aimed at the grammaticalization and lexicalization level of shui zhi dao. A methodology was presented based on the robust design approach, integrating the main hybrid process with 4 support processes for the control of performance metrics (Perez-Ruiz et al. 2020: 436). However, people's subjective feelings, attitudes or emotions received little consideration.

The above studies mainly discussed LS from the perspectives of semantics, cognitive linguistics, pragmatics, or philosophy, but scarcely from the perspective of philosophical cognition. Most of them were also restricted to a specific lexical level, seldom mentioning the syntactic and discourse levels. They were also individualised studies on either the concept of LS or its concrete means of realization, hardly on its realization mechanism. This statement holds, especially when systematically and comprehensively investigating humans' cognitive styles and ways of existence in language. No systematic or comprehensive research framework has been proposed, not to mention the study on LS under a geometric research framework. The current study constructs a systematic interactive geometric research framework of LS at six levels. This study also ensures to cover lexical, syntactic and discourse dimensions to dig the means and mechanism of the realization of LS. The study aims to explore humans' cognitive styles and ways of existence in language and to deepen the understanding of communicative functions of language. The proposed feasible analytical framework is for more deeply mining into the LS phenomenon and more profoundly interpreting the emotions, attitudes and feelings behind the speaker's words, utterances, or discourse.

The remainder of this study is organised as follows. Section 3 considers language as a hexahedron and proposes an interactive geometric research framework of LS. Section 4 explores the means and mechanism of its realization at six levels and three dimensions. Subsequently, the means and mechanism of the realization of LS and different cognitive styles and ways of existence of humans in language are obtained. Various communicative functions of LS are also discovered. Section 5 summarises the whole study and provides related conclusions.

\section{THE INTERACTIVE GEOMETRIC RESEARCH FRAMEWORK OF LINGUISTIC SUBJECTIVITY}

A research framework is constructed (Fig. 1) to investigate LS. The study hypothesises that language is a hexahedron. In the language system, the speakers and the hearers play significant roles, and all aspects of language result from their interaction in specific contexts. Outside this hexahedron, the study also considers the following points: Point S (the speaker left of the hexahedron) and Point $\mathrm{H}$ (the hearer right of the hexahedron). On the basis of the six planes of this hexahedron, the study approaches the meaning of language at six different levels: language system level (plane $\mathrm{ABCD}$ ) and language use level (plane $\left.\mathrm{A}^{\prime} \mathrm{B}^{\prime} \mathrm{C}^{\prime} \mathrm{D}^{\prime}\right)$, propositional meaning level (plane $\mathrm{A}^{\prime} \mathrm{ABB}^{\prime}$ ) and non-propositional meaning level (plane $\mathrm{D}^{\prime} \mathrm{DCC}^{\prime}$ ), speaker's encoded meaning level (plane $\mathrm{A}^{\prime} \mathrm{ADD}^{\prime}$ ) and hearer's decoded meaning level (plane $\mathrm{B}^{\prime} \mathrm{BCC}^{\prime}$ ).

In philosophy, persons have nature as subjects. Accordingly, interaction is a process of encoding and decoding meaning between speakers and hearers. So LS is also dealt with from two aspects - the speaker $(\mathrm{S})$ and the hearer $(\mathrm{H})$. On this basis, the study constructs an interactive geometric research framework of LS from the speaker's aspect and hearer's aspect (Fig. 2).

LS is a necessary component of any complete model of discourse production and interpretation. The study explores such a construct from linguistic production and linguistic interpretation in the process of language use. 


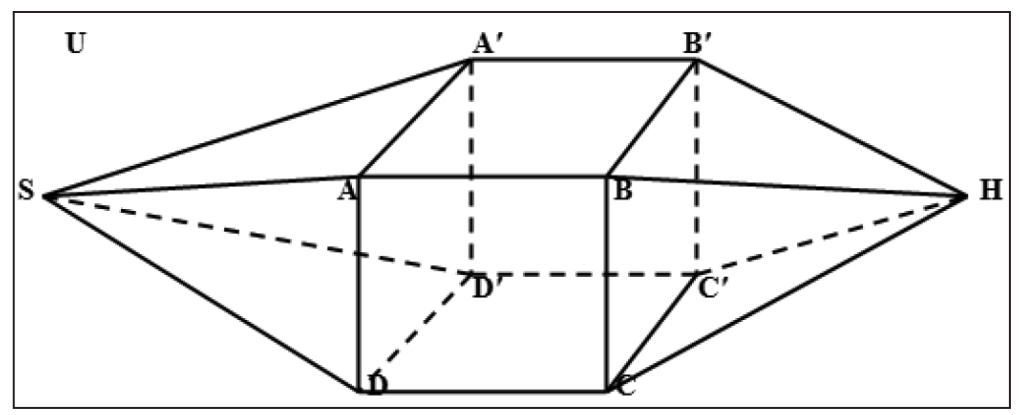

Fig. 1. The framework of linguistic subjectivity

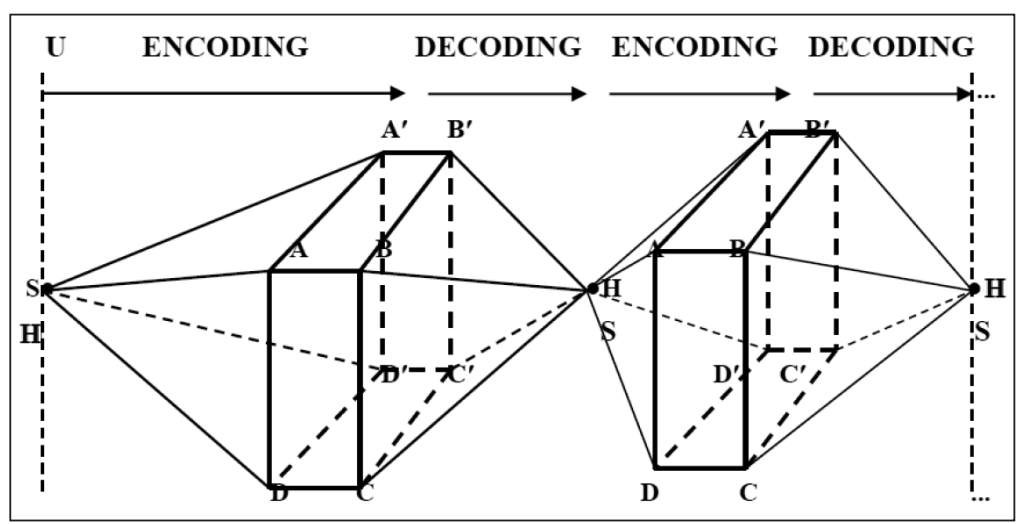

Fig. 2. An interactive geometric research framework of linguistic subjectivity

\section{MEANS AND MECHANISM OF THE REALIZATION OF LINGUISTIC SUBJECTIVITY}

\section{Linguistic Subjectivity at Language System Level}

LS is often an expression of the emotions and attitudes of the speakers toward the speech. Speakers often use language to influence the attitudes and behaviours of hearers. In such cases, modal auxiliary verbs can be used to reflect the meanings of the speakers.

For instance, they can be used by the speakers to express their propositions precisely and state uncertain propositions accurately. These verbs can show the speakers' lack of knowledge or confidence, or degrees of commitment, or what they say. They are the primary means to mark modality in English and have received much attention. They are often replaced by the term modal. This category, composed of a closed lexical class, can be further classified into the primary modal verbs (can, may, must, shall and will), the secondary modals (could, might, ought to, should and would) and quasi-modals (need to, have/got to, had better, dare, like to and used to). 
In speech communication, the modal auxiliary verbs indicate attitudes of the speaker toward the state or event expressed by another verb. They express the concepts or attitudes of possibility, probability, certainty, necessity, permission, or obligation. They reflect the existence of speakers as meaning-expressing subjects and different cognitions toward the discourse or propositions. See the following examples below:

(1) a. At this moment, Tom may (possibility) be watching TV at home.

b. It must (necessity) rain tomorrow.

c. You may (permission) not smoke here.

d. You must (obligation) finish this work before Friday.

Modal auxiliary verbs always play a significant role in implicit subjective orientation. Modal auxiliary verbs are firmly derived from subjective meaning. Modal operators can reflect the interpersonal and subjective meaning of an utterance. However, we argue that if modal auxiliary verbs are used to express the speaker's judgment, assessment, opinion and attitude, including the possibility, necessity, obligation, or permission toward the proposition, they will denote LS. This argument indicates speaker's cognition toward the objective world and demonstrates his/her ways of existence in actual discourse.

\section{Linguistic Subjectivity at Language Use Level}

When using a sentence to make a statement, speakers can encode their subjective qualifications, feelings, opinions, or attitudes into the proposition in the verbal components of their utterances. They can choose one grammatical mood rather than another. The mood is the category that results (in those languages that have it) from the grammaticalization of subjective modality and other kinds of expressive meaning, including some part of illocutionary force. Most, if not all, functions of mood are non-propositional, expressing the speaker's attitudes, feelings, or opinions toward a proposition.

In communication, the purposes are unlimited. People may want to order, apologise, confirm, invite, and evaluate something. The exchange system (giving or demanding information or goods-and-services) determines the four basic speech functions or roles (statement, question, offer and command). Three of these basic functions are closely related to particular grammatical structures (statement, question and command) most naturally expressed by declarative, interrogative and imperative clauses. These three functions are also the three main choices in the mood system of the clause. However, no one-to-one relation exists between mood and speech function. We often connect modal systems with subjunctive mood as follows:

(2) a. If I were you, I would not do that.

b. Without your help, I would not have succeeded.

(3) a. If I were you, ...

b. If I were an opera singer, ...

c. If you loved me, you would not say that.

Mood performs not only the speech function of a statement but also the speech functions of a question, offer and command. In turn, it transits the speaker's speech acts, such as politeness, effort saving, interest arousing, cooperating, hope, advice, anger, thanks, and order, indicating LS. Speakers always show themselves as the subjects in language expression in one way or another, sometimes explicitly and sometimes implicitly. 


\section{Linguistic Subjectivity at Propositional Meaning Level}

LS at propositional meaning level is reflected in the speaker's propositional attitude. A propositional attitude is a relating mental state connecting a person, usually the speaker, to a proposition. It is often assumed to be the simplest component of thought. It implies that the speaker can have different mental processes toward a proposition. This propositional attitude involves intonation and tone, which can express a variety of psychological states, such as statement, request, promise, assertion and declaration. Propositional attitude can be reflected in the verbs of propositional attitude, such as think, believe, guess, imagine, suppose, presume, understand, reckon and know.

For example, think explicates from what perspective the speaker makes comments on the propositional matter. The expression I think includes the speaker's concern for the participants (face-preserving issues and behaving like a legitimate communicator and social individual). It shows the speaker's attitudes toward the specific interactional situation at hand. It also indicates the degrees of the speaker's willingness to pursue the interactional goal and emotional involvement. See the example below:

(4) I think you'd better turn the radio down (indirect request for face-preserving).

Thus, verbs of propositional attitude are related to the speaker's attitudes, opinions and feelings, indicating LS.

\section{Linguistic Subjectivity at Non-propositional Meaning Level}

LS at a non-propositional meaning level can be reflected in affect or affective attitude. Affect refers to the experiencer's emotional attitude toward information. People's emotional states govern their perceptions of the world. They are related to the speaker's imagination world. Their meanings are endowed by the speaker either accidentally or purposefully. Therefore, the emotional state is a crucial component of the subjective interpretation of language. Thus, affect usually has a certain implication or emotional colouration. It can be hardly understood from the literal meaning, indicating the significance of intonation and context. People's emotional states affect how they talk about things. In turn, people have many ways of talking about their affective attitudes, which can be reflected in rhetorical questions, figures of speech, modal auxiliary verbs, mood, tense, aspect, adjectives, or nouns. See the examples below:

(5) a. I'm surprised that you remember so many names and addresses (surprise).

b. If only you wouldn't wear flowered pants (disapproval)!

c. You shouldn't be so indifferent (complaint)!

d. We should stay here in the shade (happiness).

e. He cannot have finished the assignment so soon (doubt).

f. I wonder what the officer want with me. I've done nothing wrong (impatience).

g. I'm sorry that in those circumstances, we were unable to hold out longer (pity).

h. I'm famished. I could eat a horse (hyperbole)!

The affective attitudes or imaginations may be different according to various speakers. For example, on the basis of different cognitions and referents, the same house may be taken as big, or considered small. They can be recognized in the judgment or evaluation of personal cognition, such as pleasantness and happiness, aesthetic judgments, such as beautiful or ugly, and value judgments, such as good or bad. These all can be used to express participants' diversified evaluations or cognitions toward the communicative objects, reflecting LS and the speakers' different cognitive styles and ways of existence. 


\section{Linguistic Subjectivity at Speaker's Encoded Meaning Level}

In terms of discourse, LS is also detected from the hearers' decoding processes. Consider the following examples:

(6) A: May I help you, Sir?

B: Yes, I'm looking for a nice gift for my girlfriend. It's her birthday tomorrow.

A: Perhaps she would like a nice necklace. We have many choices for you.

B: I don't know. She's already got one.

A: Well, then. Maybe a ring or a watch would be nice.

B: Yes, she may need a new watch. The one she's wearing is passed down from her grandmother. So, she's always late for work.

A: The gold is pretty.

$\mathrm{B}$ : Yes, it is. But are these diamonds real?

$10 \%$ off.

A: Yes, they are. This watch usually costs $\$ 3,500$. But if you buy it now, I can give you

B: It's very nice. I'll take it. Do you accept credit cards or check?

A: Both will do. But could you let me have a look at your driver's license first?

The above discourse is a whole conversation between a saleswoman (A) and a customer (B). From the beginning to the end, modality is widely used by the saleswoman. A first used the modal verb may to greet the customer, showing politeness to introduce the topic. After knowing the customer's purpose, she then used perhaps and would to make the first suggestion. The customer refused, but she continued to make the second suggestion by using maybe and would, indicating her determination to sell the goods. She succeeded in persuading the customer to buy the goods. When the customer asked the price, she used usually to indicate the usual price and can to indicate that she could cut off the price. In the end, she used will to answer the question asked by the customer to end the conversation, showing her politeness again. Finally, she used could to achieve her wanting to look at the customer's driver's license. The whole conversation can be expressed as follows:

may $\rightarrow$ perhaps $\rightarrow$ would $\rightarrow$ maybe $\rightarrow$ would $\rightarrow$ usually $\rightarrow$ can $\rightarrow$ will $\rightarrow$ could.

Modal verbs and modal adverbs in this conversation reflect some ideas of the importance of politeness in daily conversation.

\section{Linguistic Subjectivity at Hearer's Decoded Meaning Level}

Human communication is an interactive process in which the speaker and the hearer are involved, and both parties of communication are in harmony with each other. Apart from the speaker's aspect, the usually neglected hearer's aspect to explore LS is mentioned in this study.

An implicature is a contextual assumption or implication that speakers intend to make to hearers. Identification of implicature involves two tasks of cognitive inference: obtaining implicated premises and deducing implicated conclusions.

Hearers should activate or construct implicated premises from their memory or cognitive environment. Such premises should lead to an interpretation consistent with the principle of relevance, and they are manifestly the most easily accessible premises to do so. Implicated conclusions are deduced from the implicature of speaker's knowledge, cognition, utterances and the context. See the example below:

(7) A: Are you going with me to the movie, Rose?

B: I've my hands full with this report. 
In Example (9), B's utterance does not directly answer A's question. After the contextual enrichment and supplement of B's utterance, A obtains its implicature C: Rose has her hands full with her report. To identify B's communicative intention, A needs to further infer the implicated premise in context. In other words, A's task at this moment is to construct or activate the proper contextual assumption D: If someone has his/her hands full with something, he/she is busy now. This assumption is consistent with the optimal relevance of his/her cognitive environment. Depending on explicitly expressed contextual information $\mathrm{C}$ and the contextual assumption D, the hearer infers the contextual implicature E: Rose is too busy to go along.

In this way, A identifies B's communicative intention and achieves the successful communication.

\section{CONCLUSIONS}

An interactive geometric research framework of LS from the perspective of philosophical cognition was constructed to dig the complicated LS phenomenon and the means and mechanism of its realization. Humans' cognitive styles and ways of existence in language were also comprehensively explored. The means and mechanism of the realization of LS at six levels were investigated. Three dimensions were also covered in this study. The following conclusions could be drawn:

(1) The proposed interactive geometric research framework of LS can help people understand the roles played by speakers and hearers in interaction. Considering successful interaction, speakers will express their attitudes, feelings, and emotions in language. Meanwhile, hearers will interpret the self-expression of speakers by utilizing different strategies.

(2) Exploring LS from the perspective of philosophical cognition can reflect humans' cognition, cognitive styles, existence, and ways of existence and images of existence in language.

(3) Probing the means and mechanism of the realization of LS at six levels and three dimensions can comprehensively and systematically demonstrate how cognitive styles and ways of existence of humans as the meaning-expressing subjects are marked in language.

(4) Investigating the means and mechanism of the realization of LS can provide us a better understanding of LS and its essence. In this way, the emotions, attitudes and feelings behind the speaker's utterances can be thoroughly analysed to promote intercultural communication between different nationalities.

The proposed method is critical for the comprehensive and systematic study of the means and mechanism of the realization of LS. However, the study explored LS only with limited examples. More actual discourse examples may be acquired from corpora, expecting to explore the complicated language phenomenon - linguistic subjectivity - more accurately.

\section{ACKNOWLEDGEMENTS}

The reported study was funded by Humanities and Social Sciences Youth Project of the Ministry of Education, Project No. 18YJC740072.

Received 1 February 2021 Accepted 2 July 2021

\section{References}

1. Almeida, S.; Ulloa, I. 2020. 'A Conceptual Approach to the -ING Construction: Aspects of Radiality and Subjectification', Ilha do Desterro: A Journal of English Language, Literatures in English and Cultural Studies 73(1): 443-458.

2. Bale, A.; Schwarz, B. 2020. 'Proportional Readings of Many and Few: the Case for an Underspecified Measure Function', Linguistics and Philosophy 43(6): 673-699. 
3. Curşeu, P. L.; Fodor, O. C.; Pavelea, A. A; Meslec, N. 2020. “Me" Versus "We" in Moral Dilemmas: Group Composition and Social Influence Effects on Group Utilitarianism', Business Ethics: A European Review 29(4): 810-823.

4. Gerner, M. 2019. 'Assessing and Managing Sustainability in International Perspective: Corporate Sustainability Across Cultures - Towards a Strategic Framework Implementation Approach', International Journal of Corporate Social Responsibility 4(1): 1-34.

5. Langacker, R. W. 2019. 'Levels of Reality', Languages 4(2): 1-20.

6. Li, H.; Luo, M. F. 2020. 'Speaker's Cognitive Position of ShuiZhiDao and Its Subjectivity Analysis', Journal of Anshun University 22(3): 44-50.

7. Lyons, J. 1977. Semantics II. Cambridge: Cambridge University Press.

8. Mion, G.; Adaui, C. R. L. 2020. 'Understanding the Purpose of Benefit Corporations: an Empirical Study on the Italian Case', International Journal of Corporate Social Responsibility 5(1): 1-15.

9. Moghaddam, M.; Capone, A. 2020. 'Metalanguage and Subjectivity in Indirect Reports', Lingua 236(236): $1-15$.

10. Nicholas, G. 2015. Mind, Language and Subjectivity. New York: Routledge.

11. Paltrinieri, L. 2017. 'Managing Subjectivity: Neoliberalism, Human Capital and Empowerment', Fudan Journal of the Humanities and Social Sciences 10(4): 459-471.

12. Pan, H. F. 2018. 'A Multidimensional Study of Chinese Subjective Degree Adverbs - Taking he qi and he deng as Examples', Journal of Tongji University (Social Science Edition) 29(4): 115-124.

13. Peng, B. Z. 2019. 'Language Subjectivity From the Perspective of Intercultural Communication', Journal of Mudanjiang Normal University (3): 75-84.

14. Peng, Y. 2020. 'Indeterminate Self: Subjectivity, Body and Politics in Zhuangzi', Philosophy \& Social Criticism 46(3): 342-366.

15. Perez-Ruiz, J.; Martinez-Rodriguez, S.; Lopez-De La CalleMarcaide, L.; Lamikiz-Mentxaka, A.; Gonzalez-Barrio, H.; Pereira-Neto, O. 2020. 'A Robust Process for the Precision Finishing of Pieces Originated by Metallic Printing', DYNA 95(4): 436-442.

16. Petrovskaya, I.; Haleem, F. 2020. 'Socially Responsible Consumption in Russia: Testing the Theory of Planned Behavior and the Moderating Role of Trust', Business Ethics: A European Review 30(1): 38-53.

17. Traugott, E. C. 2019. Constructional Pattern-Development in Language Change. Berlin: Mouton de Gruyter.

18. Turner, K. J. 2019. 'On Subjectivity and Objectivity in the Mengzi - or Realism with a Confucian Face', Asian Philosophy 29(4): 351-362.

19. Vella, D.; Gualeni, S. 2019. 'Virtual Subjectivity: Existence and Projectuality in Virtual Worlds', Techné: Research in Philosophy and Technology 23(2): 115-136.

20. Vuković, A.; Miletić, L.; Čurčić, R.; Ničić, M. 2020. 'Consumers’ Perception of CSR Motives in a PostSocialist Society: The Case of Serbia', Business Ethics: A European Review 29(3): 528-543.

21. Wang, Q.; Li, X. J. 2019. 'The Subjective Difference Between changchang and wangwang and Its Syntactic Expression', Journal of Jiangxi Normal University (Philosophy and Social Sciences Edition) 52(3): 75-83. 


\title{
Kalbinio subjektyvumo ịgyvendinimo priemonės ir mechanizmai, žvelgiant iš filosofinio pažinimo perspektyvos
}

\begin{abstract}
Santrauka
Straipsnyje iš filosofinio pažinimo perspektyvos svarstomas kalbinio subjektyvumo (KS) reiškinys. Tyrimo tikslas - išnagrinèti kalboje išsiskleidžiančius žmogiškojo pažinimo stilius ir egzistavimo būdus, taip pat pagilinti kalbos komunikacinių funkcijų supratimą. Straipsnyje pateikiama autoriaus sukurta interaktyvi geometrinė KS tyrimų metodologine struktūra. Jos igyvendinimo priemonès ir mechanizmai tiriami šešiais lygmenimis: kalbos sistemos, kalbos vartojimo, propozicinès reikšmès (t. y. kalbètojo psichinès nuostatos sakomo teiginio atžvilgiu), nepropozicinès reikšmės (t. y. kalbėtojo emocinès nuostatos sakomo teiginio atžvilgiu), skaitytojo užkoduotos reikšmès ir klausytojo iššifruotos reikšmès. Išanalizuoti trys kalbos matmenys: leksinis, sintaksinis ir diskurso. Tyrimo rezultatai parodo, kad žmogiškojo pažinimo stiliai ir egzistavimo būdai giliau išnagrinejjami, analizuojant KS reiškinị iš filosofinio pažinimo perspektyvos. Straipsnyje pateikiama pagrịsta ir realizuojama analitinè metodologinè sistema, skirta išsamiems KS fenomeno tyrimams. Aprašytas tyrimas prisideda prie gilesnio KS ir kalbos komunikacinių funkcijų supratimo. Minètas tyrimas taip pat nuodugniai atskleidžia už kalbančiojo žodžių, pasakymų ar viso diskurso slypinčius subjektyvius veiksnius, tokius kaip nuostatos, emocijos ir jausmai, kurie, nurodydami kalbètojo egzistavimo kalboje būdus, taip pat priklauso filosofinio pažinimo kategorijai.
\end{abstract}

Raktažodžiai: kalbinis subjektyvumas, filosofinis pažinimas, igyvendinimo priemonès ir mechanizmas, pažinimo stiliai, gyvenimo būdai 